\title{
Mechanical Characterisation of Metal/Polymeric Composite Waste/Metal Sandwich Panel
}

\author{
Miroslav Müller ${ }^{1}$, Alessandro Ruggiero ${ }^{2}$, Petr Valášek ${ }^{1}$ \\ ${ }^{1}$ Faculty of Engineering, Czech University of Life Sciences Prague. Czech Republic. E-mail: muller@tf.czu.cz, vala- \\ sekp@tf.czu.cz \\ ${ }^{2}$ Department of Industrial Engineering, University of Salerno, Salerno, Italy. E-mail: ruggiero@unisa.it.
}

The aim of the paper is to compare a tensile strength and an elongation at break of the sandwich materials with different cores created with the polymeric composite mixture at simultaneous acting of the cyclic degradation. The sheet $\mathbf{S 2 3 5 J 0}$ is the face. The core of the sandwich panel is from the structural two-component adhesive, from the composite material based on the microparticles of the glass-bead, the rubber and the textile microfibre waste from the tyre recyclation and the rubber particle waste from the tyre recyclation. Namely the secondary raw materials based on the textile microfibres are difficult to utilize in another processing. This research showed one of prospective possibilities of the material utilization of this secondary raw material. The highest tensile strength of the sandwich materials is reached with the core from the composite material on the glass-bead base. The significant fall of the tensile strength of the sandwich materials was measured at the material with the core based on the rubber and textile microfibre waste from the tyre recyclation. The elongation at break was not almost changed. The core crackled at lower loading at first. The face tolerated higher loading.

Keywords: cyclic degradation, elongation at break, SEM, strength, tensile test

\section{Acknowledgement}

Supported by Internal grant agency of Faculty of Engineering, Czech University of Life Sciences Prague (2017: 31140/1312/313115).

\section{References}

[1] VALÁS̆EK, P. (2015). Polymer microparticles composites with waste EPDM rubber powder. In: Agronomy Research, Vol. 13, pp. 723-731.

[2] MÜLLER, M. (2016). Effect of saline environment on mechanical properties of structural adhesive bonds. In: Acta universitatis Agriculturae et Silviculturae mendelianae Brunensis, Vol. 64, pp. 1609 - 1617.

[3] RUGGIERO, A., VALÁŠEK, P., MEROLA, M. (2015). Friction and wear behaviors of Al/Epoxy Composites during Reciprocating Sliding tests. In: Manufacturing technology, Vol. 15, pp. 684-689.

[4] PASCUAL, C., MONTALI, J., OVEREND, M. (2017). Adhesively-bonded GFRP-glass sandwich components for structurally efficient glazing applications. In: Composite Structures, Vol. 160, pp. 560-573.

[5] CHEN, Q., LINGHU, T., GAO, Y., WANG, Z., LIU, Y., DU, R., ZHAO, G. (2017). Mechanical properties in glass fiber PVC-foam sandwich structures from different chopped fiber interfacial reinforcement through vacuumassisted resin transfer molding (VARTM) processing. In: Composites Science and Technology, Vol. 144, pp. 202207.

[6] HARHASH, M., SOKOLOVA, O., CARRADÓ, A., PALKOWSKI, H. (2014). Mechanical properties and forming behaviour of laminated steel/polymer sandwich systems with local inlays - Part 1. In: Composite Structures, Vol. 118, pp. 112-120.

[7] BELlA, G. DI., CALABRESE, L., BORSELliNO, C. (2012). Mechanical characterisation of a glass/polyester sandwich structure for marine applications. In: Materials and Design, Vol. 42, pp. 486-494.

[8] NORUZI, H., ROSTAMIYAN, Y. (2015). Experimental and numerical study of flatwise compression behavior of carbon fiber composite sandwich panels with new lattice cores. In: Construction and Building Materials, Vol. 100, pp. 22-30.

[9] LOMBARDI, N.J., LIU, J. (2011). Glass fiber-reinforced polymer/steel hybrid honeycomb sandwich concept for bridge deck applications. In: Composite Structures, Vol. 93, pp. 1275-1283.

[10] AWAD, Z.K., ARAVINTHAN, T., MANALO, A. (2012). Geometry effect on the behaviour of single and gluelaminated glass fibre reinforced polymer composite sandwich beams loaded in four-point bending. In: Materials and Design, Vol. 39, pp. 93-103. 
[11] MOUSA, S., KIM, G.Y. (2017). A direct adhesion of metal-polymer-metal sandwich composites bywarm roll bonding. In: Journal of Materials Processing Technology, Vol. 239, pp. 133-139.

[12] RUGGiero, A. MEROLA, M., CARLONE, P., ARCHODOULAKI, V.M. (2015). Tribo-mechanical characterization of reinforced epoxy resin under dry and lubricated contact conditions, In: Composite, Part B. Vol. 79, pp. 595-603.

[13] RUGGIERO, A. VALÁŠEK, P., MÜLLER, M. (2016). Exploitation of waste date seeds of Phoenix dactylifera in form of polymeric particle biocomposite. In: Investigation on adhesion, cohesion and wearn: Composites Part $B$ : Eng, Vol. 104(1), pp. 9-16.

[14] VALÁŠEK, P., RUGGIERO, A. MÜLLER, M. (2017). Experimental description of strength and tribological characteristic of EFB oil palm fibres/epoxy composites with technologically undemanding preparation, In: Composites Part B: Engineering, in press

[15] SHAO-YUN, F., XI-QIAO, F., BEMD, L., EMD, L., YIU-WING, M. (2008). Effects of particle size, particle/matrix interface adhesion and particle loading on mechanical properties of particulate-polymer composites. In: Composites: Part B, Vol. 39, pp. 933-961.

[16] LEE, J., YEEB, A.F. (2000). Role of inherent matrix toughness on fracture of glass bead filled epoxies. In: Polymer, Vol. 41, pp. 8375-8385.

[17] MÜLLER, M., CIDLINA, J., DĚDIČOVÁ, K., KROFOVÁ, A. (2015). Mechanical properties of polymeric composite based on aluminium microparticles. In: Manufacturing Technology, Vol. 15(4), pp. 624-628.

[18] KAWAGUCHI, T., PEARSON, R.A. (2013). The effect of particle-matrix adhesion on the mechanical behavior of glass filled epoxies: Part 1. A study on yield behavior and cohesive strength. In: Polymer, Vol. 44, pp. 42294238.

[19] MÜLLER, M. (2016). Mechanical properties of composite material reinforced with textile waste from the process of tyres recycling. In: Research in Agricultural Engineering. Vol. 62(3), pp. 99-105.

[20] ACEVEDO, B. FERNÁNDEZ A.M., BARRIOCANAL, C. (2015). Identification of polymers in waste tyre reinforcing fibre by thermal analysis and pyrolysis. In: Journal of Analytical and Applied Pyrolysis, Vol. 111. pp. 224232.

[21] KNAPČÍKOVÁ, L., MONKA, P., HLOCH. S (2014). Composite Materials Reinforced with Fabric from Used Tyres. In: Journal of Manufacturing and Industrial Engineering, Vol. 12(3-4), pp. 20-24.

[22] VALÁŠEK, P. (2014). Mechanical Properties of Epoxy Resins Filled with Waste Rubber Powder. In: Manufacturing technology, Vol. 14, pp. 632-637.

[23] GAGGINO, R., POSITIERI, M. J., IRICO, P., ARGUELLO, R., SÁNCHEZ AMONO, M. P. (2014). Ecological roofing tiles made with rubber and plastic wastes. In: Advanced Materials Research, Vo. 844, pp. 458-461. 